\title{
SIMPTOM MIMPI HISTERIA RASUKAN JIN DALAM PERSPEKTIF PESAKIT, PERAWAT DAN HADIS
}

\author{
Ezwan Rafiq Husin ${ }^{\mathrm{a}}$, Husin Junoh ${ }^{\mathrm{b}}$, Tamar Jaya Nizar ${ }^{\mathrm{c}}$, Kamarolzaman Md. Jidi $^{\mathrm{d}}$ \\ ${ }^{a}$ Fakulti Tamadun Islam, University Teknologi Malaysia, 81310 UTM Johor Bahru, Johor, Malaysia \\ ${ }^{b}$ Fakulti Pendidikan Teknikal dan Vokasional, Universiti Tun Hussein Onn Malaysia, Parit Raja, Batu \\ Pahat, Johor, Malaysia \\ ${ }^{c}$ Fakulti Tamadun Islam, University Teknologi Malaysia, 81310 Skudai, Johor, Malaysia \\ ${ }^{d}$ Fakulti Pendidikan Teknikal dan Vokasional, Universiti Tun Hussein Onn Malaysia, Parit Raja, Batu \\ Pahat, Johor, Malaysia \\ *Corresponding author: ezwan_rafiq@yahoo.com
}

$\begin{array}{lll}\text { Article history } & \text { Received in revised form: } 2015-02-18 & \text { Accepted: } 2015-02-18\end{array}$

\begin{abstract}
This study aims at specifying nightmares symptom of hysteria under evil possession from the perspectives of patients, therapists and Islamic Tradition of the Prophet P.B.U.H. Cases studied is on the common hysteria incidents including type of hysteria like normal possession al-sar' or al-mass, saka and withcraft hysteria. An interview survey and observation were carried out towards patients and therapists in gathering informations. The result of qualitative study is analysed thematically after a coding was done using Atlas ti. 7 Software. Experts agree to carry out on stated theme using Cohen Kappa's calculation method. Content analysis also was done to evaluate nightmare symptom of evil possession on Islamic tradition perspective. Finding shows that there were specific forms of nightmare as an evil possession symptom. This characteristic of nightmares causes sense of pain at the whole body in the next morning. Patients having nightmares before ruqyah treatment. Beside that, patients' nightmare lessens and disappears after receiveing ruqyah treatment. Symptom of behavior, physical and experience during treatment such as screaming, trembling, eyes shaking, and delusion also differentiate between hysteria evil possession from hysteria psychological disorder and evil temptation. This is due to the ruqyah treatment from al-Quran and prophet's recitement affected towards evil. It is too difficult to differentiate nightmare simptom among normal evil possession, saka and witchcraft because the most of nightmare symptom were the same as hysterical evil possession symptom.
\end{abstract}

Keywords: Symptom, nightmares, hysteria, evil possession, patient, therapist, Islamic traditions

\section{Abstrak}

Kajian ini bertujuan mengkhususkan simptom mimpi histeria rasukan jin dalam perspektif pesakit, perawat dan hadith Nabi saw. Kes histeria yang dikaji adalah secara umum merangkumi histeria rasukan biasa al-Sar' atau alMass, saka dan sihir. Temu bual dan pemerhatian dijalankan terhadap pesakit dan perawat sebagai menemukan hasil kajian secara holistik melalui triangulasi data. Dapatan kualitatif dianalisis secara tematik setelah pengekodan dilakukan menggunakan perisian Atlas ti. 7. Persetujuan pakar terhadap tema yang dinyatakan dilakukan dengan menggunakan kaedah pengiraan Cohen Kappa. Analisis kandungan turut dilakukan bagi menilai simptom mimpi histeria rasukan jin dalam perspektif hadith. Dapatan kajian menunjukkan terdapat bentuk mimpi yang khusus sebagai sebahagian dari simptom histeria rasukan jin. Simptom khusus histeria rasukan jin antaranya adalah rasa sakit pada seluruh tubuh pada keesokan harinya setelah bermimpi. Mimpi dialami sebelum pesakit menjalani rawatan ruqyah. Selain itu, mimpi berkurangan atau hilang setelah pesakit menjalani rawatan ruqyah. Simptom tingkahlaku, fizikal dan pengalaman sewaktu dirawat seperti menjerit, menggigil, mata berkedip, delusi turut membezakan pesakit histeria rasukan jin dengan gangguan jin berbentuk godaan. Hal ini, kerana rawatan ruqyah dari bacaan al-Quran dan doa-doa Nabi saw memberi kesan terhadap jin. Sukar dibezakan simptom mimpi pesakit sama ada dari jenis rasukan biasa, saka atau sihir kerana kebanyakan simptom mimpi adalah sama sebagai histeria rasukan jin.

Kata kunci: Simptom, mimpi, histeria, rasukan jin, pesakit, perawat, hadith 


\subsection{PENGENALAN}

Simptom histeria rasukan jin dengan histeria jenis lain begitu subjektif sehinggakan Henry Ey (1982) mengeluarkan empat definisi histeria. Pertama, pembohongan dan kepura-puraan atau 'Lies and Pretence'. Kedua, sindrom penyakit saraf atau 'Neurological Syndromes'. Ketiga, sebarang jenis daripada penyakit mental atau 'Other Mental Illness'. Keempat, penyakit-penyakit organik atau 'Organic Diseases'. Kekeliruan simptom ini bukan sekadar berlaku di Barat. Malah berlaku juga di dalam negara. Konflik antara ahli psikologi dengan golongan agama berlaku dalam menanggapi simptom dan punca histeria telah menimbulkan percanggahan pendapat dalam mencadangkan rawatan yang sesuai (Mohamed Hatta Shaharom, 2008). Kekeliruan ini berlaku kerana terdapat persamaan simptom mimpi antara keduadua penyakit histeria rasukan jin dengan histeria gangguan emosi. Sedangkan, pesakit histeria rasukan jin tidak semestinya mengalami histeria gangguan emosi dan begitu juga sebaliknya. Justeru, kajian ini bertujuan memperincikan simptom mimpi pesakit histeria rasukan jin dalam perspektif pesakit dan perawat supaya dapat membezakannya dengan simptom mimpi histeria gangguan emosi sebagai salah satu cabang daripada sejumlah besar simptom histeria.

\subsection{Konsep Rawatan Ruqyah dan Simptom Mimpi Histeria Rasukan Jin}

Rawatan ruqyah merupakan unsur ibadat merangkumi bacaan, tindakan, dan khidmat nasihat perawat yang harus menepati nas al-Quran dan Sunah Nabi Muhammad SAW. Prinsip ruqyah yang tiada unsur syirik adalah berdasarkan hadis Nabi SAW riwayat Muslim (t.th.: 2200). Sehubungan dengan itu, Imam al-Nawawi (1971) menyatakan bahawa ruqyah yang diharamkan sebelum ini ialah ruqyah majhulah yang tidak difahami maksudnya. Selain itu, ruqyah yang diharamkan ialah ruqyah yang ditanamkan keyakinan bahawa kesembuhan adalah berpunca daripada ruqyah tersebut sebagaimana kepercayaan masyarakat Arab Jahiliyyah sebelum kedatangan Islam. Hakikat ini dibuktikan melalui kisah generasi salaf al-șālih, iaitu tokoh tabiin yang bernama Wahab bin Munabbih (Ibn Baț̣āl, 2003: 443). Beliau telah mengarahkan pesakit sihir agar dimandikan dengan air pecahan daun Bidara yang telah dibacakan ayat Kursi dan tiga Qul (Surah al-Ikhlas, Surah al-Falaq, dan Surah al-Nas). Beliau menghuraikan amalan sebegini sebagai al-Nushrah yang dibenarkan Nabi SAW (Bukhārī, 2001: 137).

Mimpi insan bukan Nabi tidak menjadi hujah dalam kaedah pendalilan hukum-hakam syariat dalam Islam (Usāmah, 1990: 46). Hal ini demikan kerana pembentukan hukum-hakam syariat Islam dalam kaedah Ușūl al-fiqh adalah berteraskan sumber utama, iaitu al-Quran, Sunah, ijmak ulama, dan qias (alShāfi'e, 1940 dan al-Shātibí, 2002). Namun, mimpi boleh dijadikan pengalaman sebagai berita yang menggembirakan atau berita amaran (Usāmah, 1990). Tambahan lagi, Sunah menetapkan secara umum bahawa apa-apa mimpi yang menakutkan adalah daripada gangguan syaitan sebagaimana hadis-hadis dalam jadual 2.1. Menurut al-'Ayni (t.th.: 180) dalam mensyarahkan hadis riwayat al-Bukhārī (2001: 3292) berkata bahawa al-Hulm ialah mimpi yang buruk, iaitu penipuan, kejahatan, dan apa-apa yang dinisbahkan kepada syaitan bagi menimbulkan buruk sangka, kesedihan, dan kurang rasa syukur. Justeru, sumber maklumat simptom histeria rasukan jin tidak hanya diperolehi daripada al-Quran dan Sunah malah ia juga diperolehi melalui pengalaman perawat (Al-Ma'āní, 2000: 47). Contohnya, al-Quran dan Sunah tidak menyatakan keupayaan jin bertutur pelbagai bahasa menggunakan lidah manusia. Namun, Imam Aḥmad dan ayahnya mengakui berlakunya perkara tersebut (Ibn Taymiyyah, 1989).

Sehubungan itu, ulama yang terlibat dengan rawatan ruqyah membahagikan simptom histeria rasukan jin kepada dua bahagian, iaitu simptom ketika jaga dan simptom ketika tidur (Abi 'Ubaydah, 1995: 126; Wahịid 'Abd Salām Bālì, 1997: 76; al-Ma'āní, 2000a, 2000b, 2000c; Badar 'Abd al-Hamìd, 2010: 8; al-Shahodh, 2011: 99). Simptom ketika tidur ini merangkumi mimpi yang pelbagai berdasarkan pengalaman perawat. Bentuk mimpi juga tidak terikat kepada apa yang telah dinyatakan dalam al-Quran dan Sunah semata-mata. Terdapat juga sarjana yang berhujah dengan dalil daripada al-Quran dan Sunah sahaja sebagai simptom gangguan jin secara umum (Muhammad bin Sa 'íd al-Ṣaqrān, t.th; 'Abd Allah bin 'Abd al-Hamid al-Athari, t.th: 12). 
Berdasarkan teori simptom mimpi gangguan jin yang terdapat dalam jadual 2.1, adalah jelas bahawa hadis Nabi SAW secara umumnya menceritakan segala mimpi yang tidak baik berpunca daripada gangguan jin. Manakala jadual 2.2 memaparkan simptom mimpi histeria rasukan jin secara khusus berdasarkan pengalaman perawat. Hal ini demikian kerana ulama yang mengutarakan teori tersebut turut terlibat secara langsung dalam rawatan ruqyah di Semenanjung Tanah Arab.

\subsection{Simptom Mimpi Gangguan Jin Dalam Hadis}

\begin{tabular}{|c|c|c|}
\hline Bil & Sanad Hadis & Matan Hadis \\
\hline 1. & $\begin{array}{l}\text { Bukhārī (2001): no hadis: } 3292 . \\
\text { Bab: (صفة إبليس وجنوده) Sifat iblis dan tentera- } \\
\text { tenteranya. }\end{array}$ & 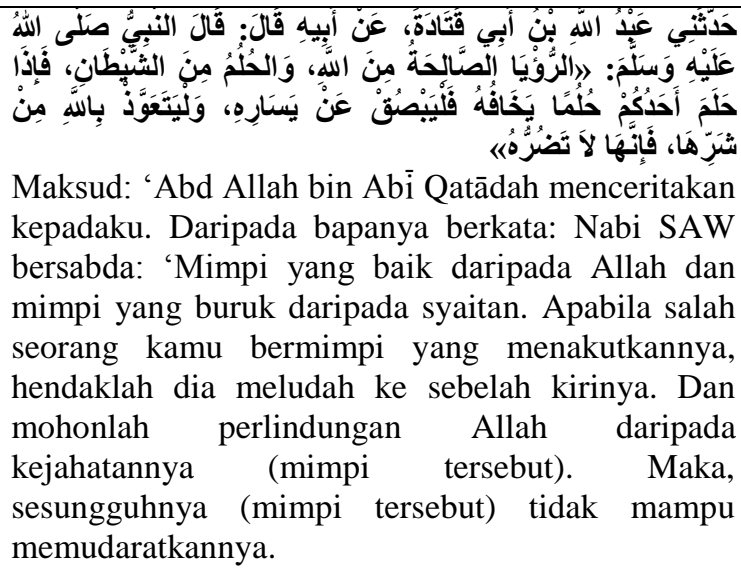 \\
\hline 2 & 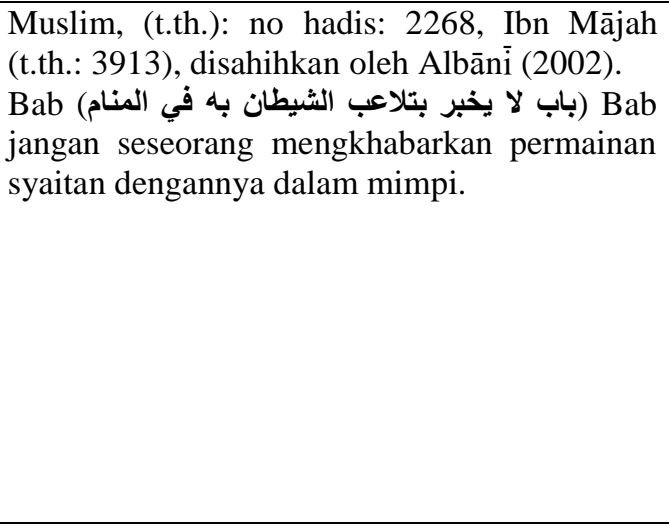 & 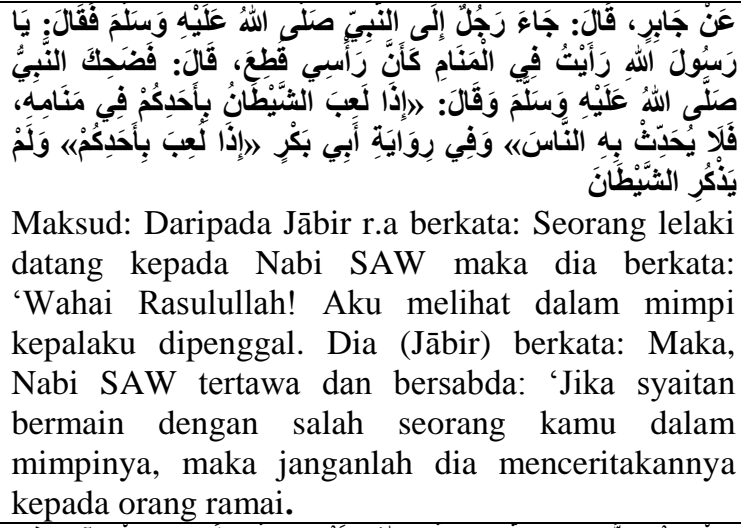 \\
\hline 3. & 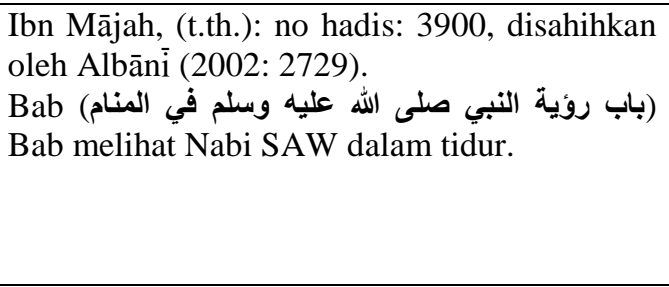 & 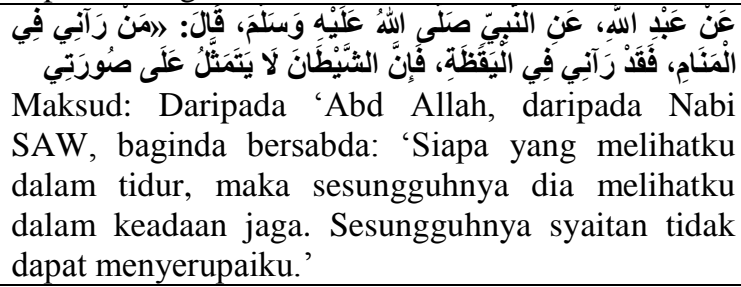 \\
\hline
\end{tabular}

Jadual 2.1: Hadis-Hadis Simptom Mimpi Gangguan Jin / Syaitan 


\subsection{Simptom Mimpi Histeria Rasukan Jin Berdasarkan Pengalaman Perawat}

\section{Jadual 2.2: Simptom mimpi Histeria Rasukan Jin / Syaitan oleh Perawat}

\begin{tabular}{|c|c|c|}
\hline Bil & Sumber & Simptom: Mimpi jatuh dari tempat tinggi \\
\hline \multirow[t]{2}{*}{1} & 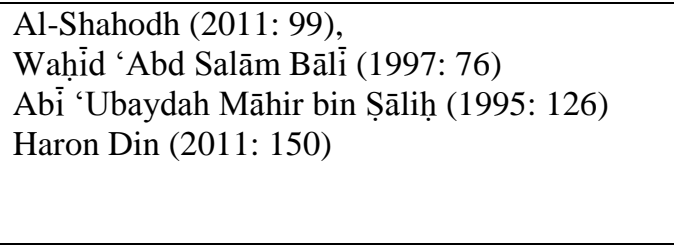 & 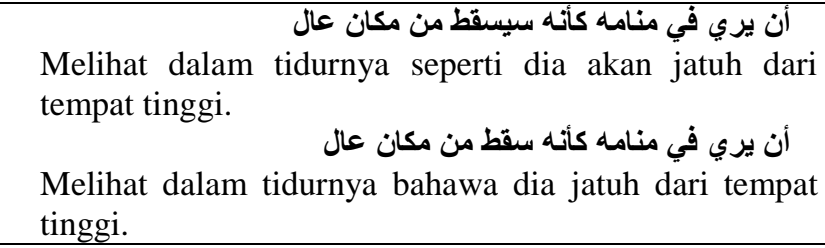 \\
\hline & & Simptom: Mimpi berada di kawasan kubur \\
\hline \multirow[t]{2}{*}{2} & $\begin{array}{l}\text { Al-Shahodh (2011: 99) } \\
\text { Wahìid ‘Abd Salām Bāli (1997: 76) } \\
\text { Abì ‘Ubaydah Māhir bin Ṣāliḥ (1995: 126) }\end{array}$ & $\begin{array}{l}\text { أن يري نفسه في مقبرة أو مزبلة أوطريق موحش } 1 \text { أو Melihat dirinya di kuburan atau tong sampah atau } \\
\text { lorong jalan. }\end{array}$ \\
\hline & & Simptom: Mimpi dikejar haiwan \\
\hline \multirow[t]{2}{*}{3} & $\begin{array}{l}\text { Wahìd 'Abd Salām Bāli (1997: 79) } \\
\text { Haron Din (2011: 150) }\end{array}$ & $\begin{array}{l}\text { Soalan: Adakah kamu melihat haiwan mengejar kamu } \\
\text { Sلرى حيوانا يطاردك في المنام؟ } \\
\text { dalam tidur? }\end{array}$ \\
\hline & & Simptom: Pelbagai mimpi yang mengerikan \\
\hline \multirow[t]{3}{*}{4} & $\begin{array}{l}\text { Waḥid ‘Abd Salām Bāli (1997: 79) } \\
\text { Abì ‘Ubaydah Māhir bin Șāliḥ (1995: 126) }\end{array}$ & ألن أحلام المزعجة أحلاما مفزعة (الكوابيس): فيري في منامه أشياء تضايقه فيحاول \\
\hline & & 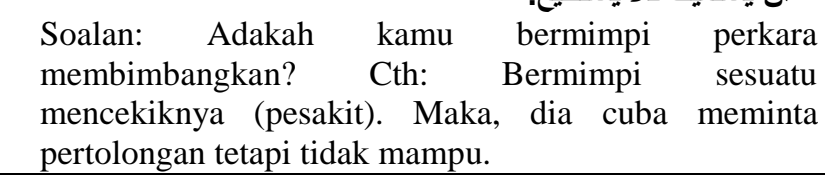 \\
\hline & & Simptom: Kancing gigi apabila bermimpi \\
\hline \multirow[t]{2}{*}{5} & 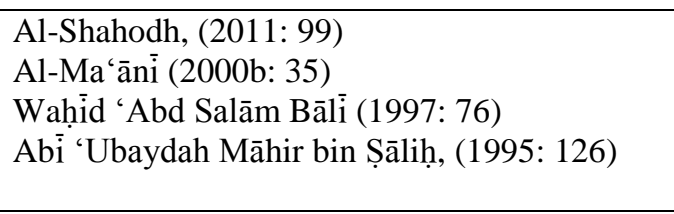 & 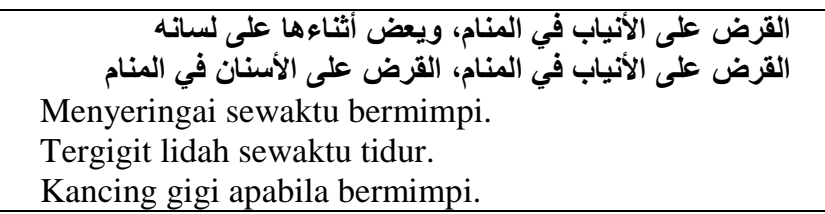 \\
\hline & & $\begin{array}{l}\text { Simptom: Ketawa, menangis atau menjerit apabila } \\
\text { bermimpi }\end{array}$ \\
\hline \multirow[t]{2}{*}{6} & $\begin{array}{l}\text { Al-Shahodh (2011: 99), } \\
\text { Wahìid ‘Abd Salām Bāli (1997: 76) } \\
\text { Abì ‘Ubaydah Māhir bin Ṣāliḥ (1995: 126) }\end{array}$ & $\begin{array}{l}\text { الضاوة في المنام البكاء أو الصر اخ في المنام } \\
\text { Ketawa, menangis atau menjerit apabila bermimpi. } \\
\text { Bangun dan berjalan dalam keadaan tidur tanpa sedar. }\end{array}$ \\
\hline & & $\begin{array}{l}\text { Simptom: Bangun dan berjalan dalam keadaan tidur } \\
\text { tanpa sedar. }\end{array}$ \\
\hline \multirow[t]{2}{*}{7} & $\begin{array}{l}\text { Al-Shahodh, (2011: 99) } \\
\text { Waḥid ‘Abd Salām Bālì (1997: 76) } \\
\text { Abَ' 'Ubaydah, Māhir bin Șāliḥ (1995: 126) }\end{array}$ & أن يقوم ويمشي وهو نائم دون أن يشعر \\
\hline & & $\begin{array}{l}\text { Simptom: Melihat haiwan atau lembaga atau hantu } \\
\text { dalam mimpi. }\end{array}$ \\
\hline 8 & 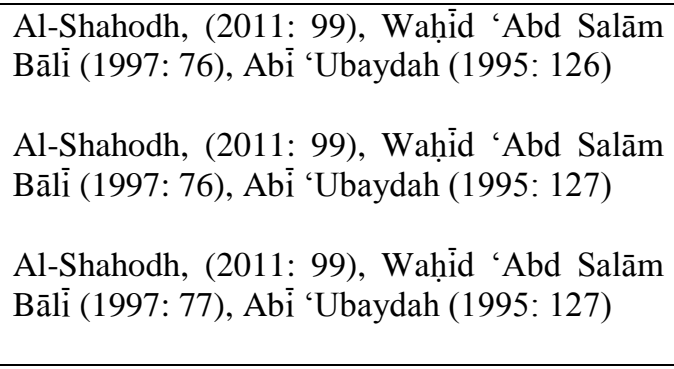 & 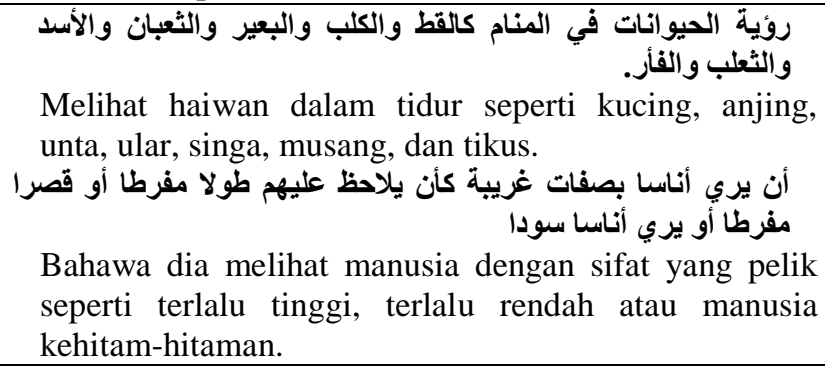 \\
\hline
\end{tabular}




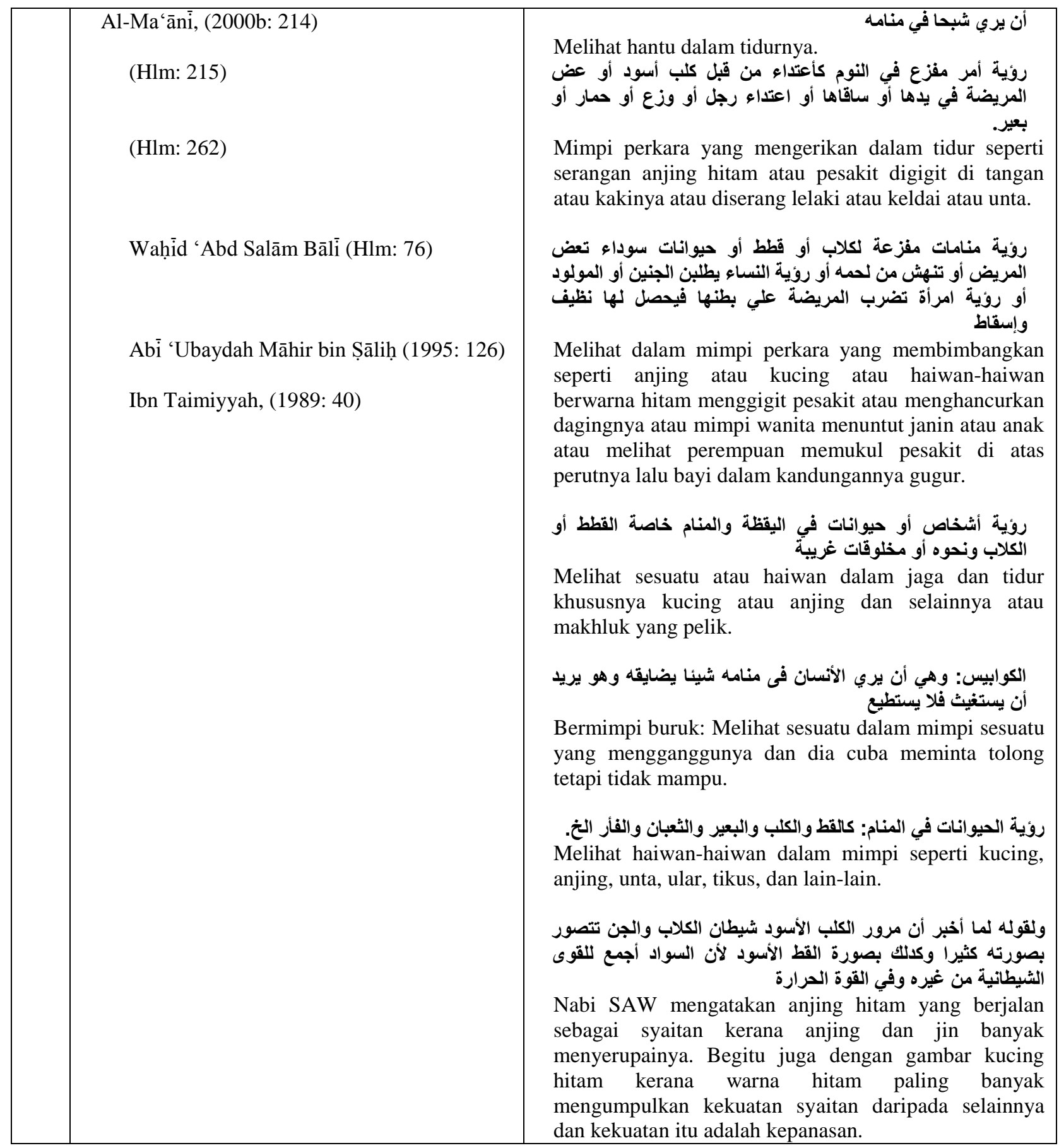




\subsection{Metodologi Kajian}

Reka bentuk kajian adalah daripada jenis kajian kes kualitatif kerana penyakit histeria rasukan jin merupakan fenomena sosial yang sesuai dikaji menggunakan pendekatan ini (Ranjit Kumar, 2005: 113). Pendekatan Kajian Kes juga digunakan untuk menunjukkan 'apakah' jenis simptom mimpi yang berlaku dan 'bagaimanakah' simptom mimpi rasukan jin tersebut berlaku (Swanborn, P. G. 2010). Data kajian pula diperoleh melalui triangulasi temu bual antara pesakit histeria rasukan jin dan perawat ruqyah sebagai analisis kualitatif. Manakala, analisis kepustakaan dijalankan bagi menilai pendirian hadis terhadap simptom mimpi histeria rasukan jin.

Kajian dijalankan di pusat rawatan ruqyah Darussyifa' di Bangi Selangor dan pusat rawatan Darussalam di Gombak, Selangor. Pemilihan kedua-dua pusat rawatan ini adalah kerana Khadher Ahmad (2012) mendapati kedua-dua pusat rawatan ini merupakan organisasi rawatan berdaftar dengan Jabatan Pendaftaran Pertubuhan atau ROS yang paling hampir kepada Sunah Nabi SAW. Pengkaji juga memilih institusi rawatan di peringkat pusat sahaja memandangkan ilmu rawatan ruqyah dan penggubalan kod disiplin ahli diasaskan dan bermula di peringkat tersebut. Seramai 12 orang pesakit dikaji, iaitu seramai enam orang pesakit Darussyifa' dan enam orang pesakit Darussalam. Keluarga pesakit diambil dalam kalangan mereka yang mampu dan sanggup memberi maklumat sahaja. Manakala, seorang perawat dari Darussyifa' dan seorang perawat dari Darussalam diambil sebagai informan temu bual. Kajian dibataskan terhadap pesakit histeria rasukan jin secara umum. Kajian ini turut membataskan simptom histeria rasukan jin dari sudut mimpi sahaja. Rawatan ruqyah yang dikaji adalah dari jenis ruqyah bagi menghindari gangguan jin sahaja.

Pengkaji menganalisis data secara tematik, iaitu mengekod perkataan atau ayat dalam temu bual yang bersesuaian dengan tema yang telah ditetapkan dalam teori kajian. Dapatan temu bual ditranskrip dan dikodkan dengan menggunakan perisian Atlas ti. 7. Persetujuan pakar diperoleh untuk mengesahkan dapatan temu bual adalah bersesuaian dengan tema kajian. Pengiraan tahap pesetujuan pakar diperoleh melalui aplikasi Cohen Kappa terhadap setiap tema. Selain itu, pengkaji juga melakukan analisis kandungan bagi menilai simptom mimpi pesakit histeria dalam perspektif hadis Nabi SAW.

Jadual 3.1: Demografi Informan Temu bual Pesakit

\begin{tabular}{|l|l|l|l|l|l|l|l|}
\hline Pesakit & Jantina & Umur & T.Tinggal & Pendidikan & Status & Pekerjaan & $\begin{array}{l}\text { Bil } \\
\text { Anak }\end{array}$ \\
\hline S1 & Wanita & 30 & Putrajaya & $\begin{array}{l}\text { Ijazah Sarjana } \\
\text { Muda }\end{array}$ & Berkahwin & Pegawai Bank & 1 \\
\hline S2 & Wanita & 28 & Kajang & SPM & Berkahwin & Polis & - \\
\hline S3 & Wanita & 54 & Selangor & SPM & Janda & Suri Rumah & 4 \\
\hline S4 & Lelaki & 61 & Subang & SRP/LCE & Berkahwin & Tentera & 3 \\
\hline S5 & Wanita & 49 & Bangi & $\begin{array}{l}\text { Ijazah Sarjana } \\
\text { Muda }\end{array}$ & Berkahwin & Guru & 1 \\
\hline S6 & Wanita & 45 & Bangi & SPM & Janda & Berniaga & 5 \\
\hline S7 & Wanita & 57 & Bangi & SPM & Janda & Suri Rumah & 6 \\
\hline S8 & Lelaki & 32 & Serdang & $\begin{array}{l}\text { Ijazah Sarjana } \\
\text { Muda }\end{array}$ & Berkahwin & Guru & 1 \\
\hline S9 & Wanita & 36 & Dengkil & $\begin{array}{l}\text { Ijazah Sarjana } \\
\text { Muda }\end{array}$ & Berkahwin & Guru & 3 \\
\hline S10 & Wanita & 49 & Serdang & SPM & Berkahwin & Suri Rumah & 6 \\
\hline S11 & Wanita & 45 & Putrajaya & Diploma & Berkahwin & $\begin{array}{l}\text { Setiausaha Syarikat } \\
\text { GLC }\end{array}$ & 1 \\
\hline S12 & Wanita & 44 & Batu Caves & SPM & Berkahwin & Pekerja Bank & 5 \\
\hline
\end{tabular}




\subsection{Dapatan Kajian}

Berikut merupakan dapatan daripada analisis yang telah dijalankan. Perbincangan adalah mengikut tema-tema seperti berikut:

\subsection{Mimpi Jatuh Dari Tempat Tinggi}

Pesakit 'S1' (2014: 707) berkata: 'Ar, tu pun biasa. Tu benda biasa. Ar, jatuh dari tempat tinggi.' Pesakit 'S5' (2014: 430) pula berkata: 'Memang. Sebelum makcik sakit dulu. Makcik selalu bermimpi err, terbang. Pesakit 'S5' (2014: 734) berkata lagi: 'Kalau tahun lepas, masih lagi bermimpi orang masukkan kita dalam parit kecik yang dalam. Tapi, dalam mimpi tu boleh ingat. Boleh ingat pada Allah. Boleh beristighfar. Boleh sebut Allahu Akbar. Dalam mimpi yang dia masukkan kita dalam parit kecik yang dalam supaya kita mati tu. Kita kata oh! Takde lain yang aku boleh ar, sedar. Satu sahaja. Hanya dengan menyebut kalimah Allahu Akbar. Bila makcik sebut kuat-kuat Allahu Akbar. Memang tersedarlah. Pesakit 'S7' (2014: 1199) berkata: 'Padahal, tidur baru tidur. Ha! Dalam pukul sepuluh sebelas tu karang. Baru tidur. Baru letak. Dalam, dalam, dalam setengah jam je dah menjerit. Macam orang hempap kita. Orang kejar kita. Jatuh dari tempat tinggi.'

Pesakit 'S7' (2014: 1671) berkata: 'Lepas tu jatuh daripada tempat tinggi. Kita dah jatuh lepas tu menjerit. Orang kejar, sekuat-kuat hatilah kita berlari-lari, orang dah kejar. Kejar nak kejar kita. Lepas tu menjeritlah. Tu, menjerit tu diorang tengah tidur. Tak perasan huhuhu (ketawa).. Pesakit 'S8' (2014: 250) pula berkata: 'Mimpii, jatuh tempat tinggi. Mimpi apa? Dikejar dengan ular. Mimpi macam-macam. Mimpi ar, mimpi nampak alat-alat orang buat bomoh tu ha! Peralatan semah la. Mimpi macam berasap je kan? Pesakit 'S9' (2014: 1738) berkata: 'Mimpi yang mengerikanlah hehehe (ketawa). Yang tak suka, mimpi ular tu lah. Baby jatuh. Baby jatuh bangunan.' Menerusi huraian yang lain, pesakit 'S9' (2014: 193) berkata: 'Macam nak jatuh. Tapi, sebenarnya, macam nak terjatuh katil hehehe (ketawa). Macam tu adalah. Tapi, biasa mimpi tu lah. Baby jatuhkan, daripada bnagunan. Bangunan tinggi ar.' Beliau (2014: 442) berkata lagi: 'Macam kita tak dapat selamatkan dia. Nampak tengok dia.' Pesakit 'S11' (2014: 15) juga berkata: 'Mimpi dikejar binatang. Lepas tu, kita jatuh dekat bangunan tinggi. Ha! Macam tu lah.' Pesakit 'S12' (2014: 2436) merangkumkan semua jawapan dengan berkata: 'Ada. Banyak kali. Jatuh, ular. Awak sebut je. Itu saya kata. Agaknya, dia bagai all means kot. Sebab tu saya kata dia ni by all means.' Beliau juga pernah bermimpi jatuh di rumah lama dengan katanya: 'Rumah lama ada. Saya jatuh. Ya Allah! Rumah yang buruk-buruk tu kan. Saya dekat atap dia kan. Jatuh. Jatuh. Bukan jatuh betul. Tapi, by the time dah nak jatuh tu mimpi hilang. Kan kita dah tahu biasa macam tu kan. Mimpi hilang tak tahu penghujungnya kan. Saya selalu macam tu mimpi saya (S12, 2014: 2659).'

\subsection{Mimpi Berada Di Kawasan Kubur, Sampah atau Rumah Lama}

Pesakit 'S12' (2014: 1018) berkata: 'Rumah lama ada. Saya jatuh. Ya Allah! Rumah yang burukburuk tu kan. Saya dekat atap dia kan. Jatuh. Jatuh. Bukan jatuh betul. Tapi, by the time dah nak jatuh tu mimpi hilang. Kan kita dah tahu biasa macam tu kan. Mimpi hilang tak tahu penghujungnya kan. Saya selalu macam tu mimpi saya.'

\subsection{Mimpi Dikejar Haiwan, Lembaga atau Hantu dan Dicekik}

Pesakit 'S1' (2014: 3638) berkata: 'Mimpi yang menakutkan tu biasa. Contoh, macam ular. Ar, kala jengking. Ar, kita mimpi perkara-perkara yang ngeri. Ar, tu memang biasa. Ar, lintah. Kita, dan mimpi ni, kalau daripada pengalaman, kalau mimpi. Then, akan sakit. So, maksudnya, mimpi tu sebaga satu petanda.' Menerusi pertanyaan lain, beliau berkata: 'Ar, ada. Mimpi dikejar anjing hitam. Lintah hisap darah kita. Ar, ular. Ataupun, sometimes kita mimpi benda menyerupai seseorang datang nak mengganggu. Ar, macam tu lah (S1, 2014: 450).'

Pesakit 'S2' (2014: 1192) berkata: 'Orang tua ar, selalu tengok kita. Kadang dia dengan keris. Kadang ar, masa tu seolah dia manipulate kita dalam mimpi pun ada jugak.' Pesakit 'S3' (2014: 2124) berkata: 'Saya nampak satu makhluklah. Ar, macam kita jugak. Tapi, dan saya kenal makhluk tu. Tapi, 
dia berubah dalam keadaan yang orang kata. Dahsyatlah. Mengerikanlah macam tu. Dia datang dalam keadaan muka yang bengis kan. Tapi, daripada muka tu kita dapat tahu lah sapa. Ha! Selalulah datang dalam mimpi.'

Berkenaan mimpi melihat lembaga aneh, pesakit 'S4' (2014: 2171) berkata: 'Hah. Dia serba hitam. Tak nampak muka. Tapi, hitamlah.' Lembaga tersebut sering memerhatikan beliau dalam mimpi (S4, 2014: 1332).' Pesakit 'S5' (2014: 501) berkata: 'Selain daripada terbang sebelum tu mimpi anjing kejar. Lepas tu, ular. Ar, tu memang. Melalui mimpi macam tu lah. Lepas tu sebelum sakit. Bila dah sakit tahun lepas. Tahun ni, Alhamdulillah pulak takde mimpi-mimpi yang teruk macam tu.' Beliau berkata lagi: 'Anjing hitam memang selalu. Lepas tu besar-besar pulak dia mengejar (S5, 2014: 1346).' Pesakit 'S6' (2014: 1134) bermimpi didatangi wanita tua yang membawa anak. Mimpi tersebut berulang-ulang. Kadangkala, beliau bermimpi melihat hantu dengan wajah yang mengerikan.

Pesakit 'S7' (2014: 1199) berkata: 'Padahal tidur baru tidur. Ha! Dalam pukul sepuluh sebelas tu karang. Baru tidur. Baru letak. Dalam. Dalam setengah jam karang dah menjerit. Macam orang kejar kita, orang hempap kita. Jatuh dari bangunan tinggi.' Selain itu, beliau turut bermimpi dikejar orang (S7, 2014: 1598). Beliau turut berkata: 'Lepas tu, jatuh daripada tempat tinggi. Kita dah jatuh lepas tu menjerit. Orang kejar sekuat-kuat hatilah. Kita berlari-lari, orang dah kejar. Kejar nak kejar kita. Lepas tu menjerit lah. Tu menjerit tu, diorang tengah tidur. Tak perasan. Huhuhu (ketawa) (S7, 2014: 1671).' Berkenaan mimpi dikejar binatang, beliau berkata: 'Binatang. Hah! Mimpi ular. Ular dua ekor. Ular dua ekor. Mungkin dia patuk dekat kaki tu (S7, 2014: 131).' Beliau menghuraikan lagi dengan katanya: 'Ular dua ekor. Satu tak patuk. Satu dia patuk. Yang dia patuk tu yang dekat hujung kaki lah. Ha! Dia patuk, nampak dia patuk. Lepas tu, terus dia lari. Yang satu tu tak patuk, dia tengok je. Tak tahu lah dia nengok tu nak patuk ke tidak tak tahu (S7, 2014: 271).' Beliau bermimpi dan dikejar sehingga terjatuh sebagaimana kata beliau: 'Tapi, dikejar. Jatuh tu memang ada (S7, 2014: 1128).'

Pesakit 'S8' (2014: 250) berkata: 'Mimpii. Jatuh tempat tinggi. Mimpi apa? Dikejar dengan ular. Mimpi, macam-macam. Mimpi nampak seolah-olah alat orang buat bomoh tu. Hah! Peralatan semah la. Semah pun saya nampak. Mimpi macam berasap je kan.' Pesakit 'S8' (2014: 912) menyatakan ular yang mengejar beliau dalam mimpi bewarna hitam dari jenis ular tedung. Pesakit 'S9' (2014: 1058) turut mengalami perkara yang sama. Pesakit 'S9' (2014: 1738) berkata: 'Mimpi yang mengerikanlah. Hehehe (ketawa). Yang tak suka mimpi ular tu lah. Baby jatuh. Baby jatuh bangunan.' Berkenaan mimpi ular, beliau berkata: 'Ada dua tiga kalilah. Mimpi ular tu pun dua tiga kali jugak (S9, 2014: 1894).'

Pesakit 'S10' (2014: 1289) pula bercerita: 'Saya selepas dirawat hari tu ada mimpi. Saya mimpi dua ekor ular cuba attack saya tau. Saya mintak tolong. Saya tak tahu siapa keliling saya ni tau. Saya mintak tolong orang tu ambikkan parang. Sebab nak membunuh ular ni. Jadi, bila orang tu nak ambik. Lepas tu, ular tu loncat belakang dia tau. Gigit belakang dia tau. Terus dia jatuh. Dia jatuh, saya dah ketakutan tau. Saya tanya mana parang? Tapi, tak sangka-sangka parang tu ada dekat sebelah saya tau. Tersedar, eh! Saya mimpi. Saya mimpi takutlah ular nak anu kita kan. Tapi, saya tahulah kalau mimpi-mimpi tu tak bagus kan.' Selain itu, pesakit 'S10' (2014: 175) turut bermimpi dikejar haiwan berbulu. Beliau berkata lagi: 'Mimpi ular tu sekali je. Betul, betul (S10. 2014: 513). Menurut beliau lagi: 'Lepas tu ada ganggu dengan binatang, binatang (S10, 2014: 127).'

Pesakit 'S11' (2014: 2087) berkata: 'Dia selalu kita mimpi yang. mimpi macam binatang gitu kan. Nak gigit kita kan.' Beliau menguatkan lagi gabungan mimpinya dengan berkata: 'Mimpi dikejar binatang lepas tu kita jatuh dekat bangunan tinggi. Ha! Macam tu lah (S10. 2014: 15).' Beliau berkata: 'Binatang yang kadang kucing, ular tedung ha (S10, 2014: 150).' Beliau menyatakan kucing tersebut berwarna biasa (S10, 2014: 268). Pesakit 'S12' pula sering bermimpi dikejar ular hitam (S12, 2014: 2436).' 


\subsection{Ketawa atau Menangis atau Menjerit atau Kancing Gigi apabila Bermimpi}

Saksi pesakit 'S7' (SS7, 2014: 145) berkata: 'Pernah mak tidur malam tu menjerit. Nyaring sangat. Rasanya rumah sebelah pun boleh dengar.' Pesakit 'S7' (2014: 1018) berkata: 'Cakap apa sikit macam nak marah dah. Macam kadang dengor dekat rumah macam ada benda. Tidur malam meracau. Selalu. Boleh kata tiap-taip malam. Pukul dua belas ke. Ar. Mesti meracau. Ar. Macam orang kejar kita lah. Apa? Mimpi yang tak baiklah kan.'

Isteri pesakit 'S8' (SS8, 2014: 113) pula berkata: 'Suami saya tidur kadang mengaduh sakit. Macam kena pukul. Lepas tu geleng-geleng kepala meronta-ronta. Bila saya kejutkan tu, baru dia sedar mengucap dan istighfar.' Ibu pesakit 'S12' (2014: 232) pula berkata: 'Anak saya tu sebelum tidur saya mesti nak ingatkan dia supaya amalkan surah tiga Qul macam ustaz ajar. Kalau dia lupa aje siaplah. Memang malam-malam selalu menjerit atau menangis. Kadang boleh ketawa pulak.' Pesakit 'S12' (2014: 2158) berkata: 'Haritu memang mengigau boleh tahanlah sebab saya memang. Haritu, saya mengerang kesakitan sebab benda tu menyerang. Bila benda tu menyerang tengah mimpi. Kita sakitkan. Ruparupanya dia menyerang kita dalam mimpi. Dan kita mimpi pun kena serang. Bila saya sedar tu saya masih sakitlah.'

Merujuk kepada rasukan yang kuat seperti dialami pesakit 'S12' (2014: 1221), mimpi buruk beliau berulang sesudah beliau menjalani rawatan. Situasi ini berlaku pada permulaan beliau menjalani rawatan dengan Darussalam. Pesakit 'S12' (2014: 4551) berkata lagi: 'Alhamdulillah. Mimpi saya dah makin kurang sejak berubat dengan Darussalam ni. Tapi, walau macam mana pun, saya tetap kena datang berubat lagi sampai saya betul-betul sembuh.' Pesakit 'S12' (2014: 2854) juga mengakui beliau mengalami kancing gigi apabila bermimpi.'

Jadual 4.1: Bacaan Cohen Kappa Terhadap Pengesahan Tema Kajian

\begin{tabular}{|l|l|l|l|}
\hline Bil & Tema & Cohen Kappa & Tahap \\
\hline 1 & Mimpi Jatuh Dari Tempat Tinggi & 0.85 & Almost Perfect \\
\hline 2 & Mimpi Berada Di Kawasan Kubur, Sampah atau Rumah Lama & 0.55 & Moderate \\
\hline 3 & Mimpi Dikejar Haiwan, Lembaga atau Hantu dan Dicekik & 0.85 & Almost Perfect \\
\hline 4 & $\begin{array}{l}\text { Ketawa atau Menangis atau Menjerit atau Kancing Gigi } \\
\text { Apabila Bermimpi }\end{array}$ & 0.60 & Moderate \\
\hline
\end{tabular}

\subsection{Ulasan Perawat Terhadap Simptom Mimpi Rasukan Jin}

Perawat 'R1' (2014: 2642) berkata: 'Dia kalau mimpi ni memang kita ambik karangan para ulama tu sebagai rujukan kita. Memang kalau pesakit mengadu dekat kita selalu mimpi dikejar ular hitam, kucing hitam, anjing hitam, nampak lembaga dan sebagainya. Kita syak itu tanda-tanda gangguan. Namun, nak meletakkan seratus peratus mimpi macam berpunca dari gangguan jin, itu saya tak berapa setuju. Pada saya, kita kena rawat dia dan tengok kesan rawatan pada dia. Kalau lepas rawat, kita tengok mimpi dia berkurangan atau hilang. Maka, kita boleh andaikan mimpi tu sebagai simptom histeria rasukan jin. Tapi, kalau kita dah rawat pun, dia masih bermimpi lagi, biasanya mimpi tu disebabkan gangguan emosi macam trauma, stres, sedih, dan banyak lagi lah. Saya tak setuju kalau semua benda dikaitkan dengan gangguan jin. Walau jin boleh mengganggu banyak urusan manusia.'

Berkenaan mimpi, perawat 'R2' (2014: 669) pula berkata: 'Kita, pada peringkat awalnya begitulah. Sebagai. Kita berkenaan tafsir mimpi ni kita tak begitu arif. Kita hanya berdasarkan pengalaman apa tu? Kitab-kitab muktabar. Dari ulama-ulama yang maknanya. Ulama-ulama silamlah. Lebih-lebihlah lagi mereka yang dah terlibat dengan rawatan kan. Diorang menulis buku. Jadi, so kita boleh ambil daripada situ. Namun, kesahihannya, kita tak pasti. Kita boleh ambik sebagai, kata orang tu maklumat awal. Sebelum kita membuat rawatan. Sebab tu, kadang kita buat rawatan kita boleh tanyalah. Mana tahu sakit? Ar, dia kata saya selalu mimpi sekian, sekian, sekian. Selalu mimpi ular. Selalu mimpi baby. Ar, Tapi, 
adakah sandaran tu kita nak ambik kesimpulan dia tu ada gangguan. Belum. Belum pasti sehingga kita baca ayat-ayat shifa' yang ada gangguan terhadap dia lah. Tapi, kalau kita baca pun dia tak rasa apa-apa. Dia rasa tenang je, takde rasa. Mungkin dia ada tekanan jiwa kan. Bukan menyebabkan gangguan.

Beliau berkata lagi: 'Sebab tu, kita boleh jadikan petanda awal dia ada gangguan. Itu boleh dijadikan sebagai sandaran awal lah. Ar, tapi jangan kita conform. Sebab setengah pusat rawatan kadang mimpi baby terus dia sembilan puluh sembilan point sembilan peratus ar, yang ni saka. Pada saya benda tu tak boleh nak conform kan lagi lah. Kan. Walaupun benda tu ada kebenaran dia dalam rawatan yang sebelum ni. Tapi, tak boleh buat statement macam tu sebenarnya. Kan. Pada sayalah. Sehinggakan kita pastikan betul sebab benda ni. Rawatan ni kena buat susulan. Dia tak boleh buat sekali. So, orang yang demam pergi klinik, dia bagi antibiotik. Bagi panadol. lepas tu dia makan sembuh. Rawatan tak macam tu. Rawatan tu dia kena berkali-kali (R2, 2014: 1400).'

Berdasarkan dapatan temu bual pesakit dan perawat, pengkaji mencadangkan agar kesan rawatan ruqyah ke atas mimpi pesakit diambil kira sebagai mengkhususkan simptom mimpi histeria rasukan jin berbanding histeria akibat trauma atau gangguan emosi. Sebagai contoh, mimpi akan berkurangan atau hilang setelah pesakit dirawat secara ruqyah menunjukkan mimpi tersebut adalah simptom histeria rasukan jin. Selain itu, simptom mimpi histeria rasukan jin dapat dikhususkan apabila mimpi tersebut berkisar tentang isu-isu yang telah dinyatakan pada jadual 2.1 dan 2.2 tersebut. Sedangkan, pesakit histeria akibat trauma kebiasaannya mengalami mimpi berkaitan dengan pengalaman buruk mereka sahaja seperti peperangan, keganasan, kemalangan dan sebagainya (Matus, J. L. 2008: 59; Ray, S. L. 2008: 218; Dayan, J. dan Olliac, B. 2010: 297).

\subsection{Simptom Tingkahlaku, Fizikal dan Pengalaman Histeria Rasukan Jin}

Istilah 'rasukan jin' berbeza dengan 'gangguan jin'. Kalimah 'rasuk' menurut Kamus Dewan bermaksud 'masuk'. Manakala, 'ganggu' bermaksud 'mengusik, mengacau, menggoda, mempermainmainkan'. Istilah bahasa Arab yang lebih sinonim dengan 'rasukan' ialah (صرع) yang (صرع) atau bermaksud 'menyentuh' atau 'memukul' jin. Istilah 'sentuhan syaitan' hanya disebut dalam surah alBaqarah (2: 275) dan Șad (38: 41). Manakala istilah yang banyak digunakan dalam al-Quran dan hadis

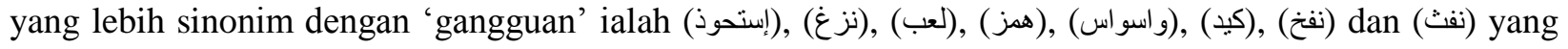
bermaksud: 'menguasai, mengganggu, mempermainkan, menghasut, membisik, menggoda, meniup dan menyimpul'.

Pesakit yang dirasuk jin adalah termasuk antara pesakit yang diganggu jin. Tetapi, tidak semestinya insan yang diganggu jin bermaksud dia dirasuk jin. 'Gangguan' boleh bermaksud hasutan atau godaan sahaja. Maka, ciri khusus pesakit histeria rasukan jin ialah simptom tingkahlaku, fizikal dan pengalaman yang terzahir sewaktu mereka diruqyah. Simptom ini bertindak memastikan simptom mimpi yang dialami juga adalah daripada rasukan jin. Simptom ini telah dinyatakan oleh ulama yang terlibat dalam rawatan ruqyah seperti tubuh menggigil, sakit seluruh tubuh, mata berkedip, menjerit dan banyak lagi (Abi 'Ubaydah, 1995; Wahīi, 1997; al-Ma'āni, 2000a dan b; al-Shahodh, 2011 dan Haron Din, 2011 dan 2015). Keseluruhan informan pesakit didapati menunjukkan simptom tingkahlaku dan fizikal histeria rasukan jin yang membezakan diri mereka daripada pesakit histeria traumatik dan gangguan jin berbentuk hasutan atau godaan (Ezwan Rafiq et al. 2015).

\subsection{Kesan Rawatan Ruqyah Terhadap Mimpi Pesakit Histeria}

Keseluruhan pesakit mengakui bahawa mimpi menakutkan yang mereka alami semakin berkurangan setelah menjalani rawatan ruqyah di Darussyifa' dan Darussalam. Mimpi yang masih berulang juga menunjukkan kekerapan berulang yang rendah. Mimpi menakutkan biasanya berulang apabila pesakit tidak menjaga kualiti amalan bacaan al-Quran dan zikir sebagaimana yang diajar oleh perawat. Mimpi menakutkan juga berulang jika pesakit tidak mengulangi rawatan. Secara keseluruhannya, hanya pesakit 'S11' (2014: 88) sahaja yang mengalami masalah gangguan emosi yang turut mempengaruhi corak mimpinya. Hal ini, kerana pesakit mengakui turut menghadapi masalah kekeluargaan selain mengalami histeria rasukan jin. Manakala, para pesakit yang lain didapati tidak menghadapi apa-apa masalah emosi 
sebagai faktor sampingan terhadap mimpi buruk yang dialami. Mimpi buruk sebagai simptom histeria rasukan jin semakin teserlah apabila dibacakan ruqyah berdasarkan reaksi dan simptom fizikal histeria

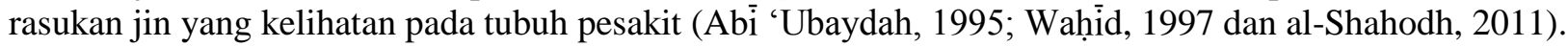

\subsection{PERBINCANGAN}

Seramai tujuh orang pesakit telah mengalami simptom jatuh dari tempat tinggi. Mereka ialah pesakit 'S1', pesakit 'S5', pesakit 'S7', pesakit 'S8', pesakit 'S9', pesakit 'S11' dan pesakit 'S12'. Mimpi ini berlaku dalam keadaan mereka sedang jatuh atau mereka terasa hampir terjatuh. Kebiasaan mimpi mereka menunjukkan mereka berada di puncak yang tinggi seperti bangunan, rumah lama, longkang, parit dan sesuatu yang kelihatan mempunyai jurang yang dalam. Hal ini adalah menyamai apa yang telah dinyatakan (Abi 'Ubaydah, 1995; Wahịd 'Abd Salām Bāli, 1997, al-Shahodh, 2011 dan Haron Din, 2011). Kebiasaannya, mimpi berakhir apabila pesakit berada dalam keadaan jatuh dan seolah tiada penghujung cerita. Selain itu, simptom ini juga boleh berbentuk melihat bayi yang dicampak dari bangunan yang tinggi. Mereka berasa kasihan dan ingin membantu tetapi tidak mampu berbuat apa-apa. Simptom mimpi seperti ini bertujuan menimbulkan perasaan sedih dan takut sebagai gangguan terhadap emosi pesakit. Pesakit 'S5' berada dalam keadaan separa sedar kerana beliau mampu mengucap Allahu Akbar dan tersedar daripada mimpi. Hal ini menunjukkan bahawa bacaan ruqyah sama ada daripada pesakit atau perawat memberi reaksi terhadap mimpi dan mengkhususkan mimpi tersebut sebagai simptom rasukan jin. Berkenaan mimpi berada di kawasan kubur, sampah atau rumah lama, mimpi ini hanya dialami pesakit ' $\mathrm{S} 12$ ' dan juga berkesinambungan dengan mimpi terjatuh dari bangunan tinggi yang telah disebutkan.

Mimpi dikejar haiwan, lembaga atau hantu juga merupakan simptom signifikan yang dialami pesakit histeria rasukan jin. Mimpi ini hadir dalam pelbagai versi menunjukkan kekuatan gangguan jin yang dihadapi pesakit. Apabila pesakit bermimpi pada hari tertentu maka pada keesokan harinya mereka akan merasa sakit. Situasi ini memiliki persamaan dengan teori kajian (Abi 'Ubaydah, 1995; Wahìd 'Abd Salām, 1997, al-Shahodh, 2011 dan Haron Din 2011). Haiwan, lembaga atau hantu yang mengejar kebiasaannya berwarna hitam. Situasi ini berlaku kerana warna hitam melambangkan kekuatan syaitan dan bersifat panas sebagaimana dinyatakan oleh Ibn Taimiyyah (1989: 40).

Kadangkala, para pesakit bermimpi direnung oleh orang tua yang berpakaian tradisional melambangkan kebudayaan atau keagamaan tertentu. Adakala, pesakit direnung oleh wanita tua yang membawa anak. Sesetengah mimpi pula menunjukkan orang tua atau wanita yang merenung pesakit bertukar wajah menjadi hodoh dan mengerikan. Merujuk keadaan yang lebih kritikal, lembaga tersebut akan bertindak mencekik atau menindih pesakit disertai dengan bunyi dengung pada telinga. Situasi seperti ini sudah cukup untuk membuat pesakit menjerit dan menggelupur apabila bermimpi. Pesakit terasa ingin melepaskan diri daripada dicekik atau ditindih tetapi tidak mampu. Mimpi tersebut kebiasaannya berakhir apabila pesakit menjerit Allahu Akbar atau dikejutkan oleh ahli keluarga atau berakhir dengan sendiri secara tiba-tiba. Bagaimanapun, asas simptom mimpi yang dialami adalah menyamai dengan apa yang telah dinyatakan oleh Abí 'Ubaydah (1995), Waḥid 'Abd Salām Bāli (1997) al-Shahodh (2011) dan Haron Din (2011).

Tindakan ketawa, menangis atau menjerit apabila bermimpi merupakan sekuen daripada simptom mimpi ngeri yang telah dinyatakan. Adakalanya, pesakit menyedari dan memberi reaksi terhadap mimpi sama ada menjerit, mengaduh atau menangis. Kadangkala, pesakit dikuasai jin menyebabkannya ketawa dalam mimpi. Kadangkala, pesakit menjerit 'Allah Akbar!' untuk melepaskan diri daripada gangguan mimpi. Adakalanya pesakit tidak menyedari apa yang berlaku melainkan setelah diceritakan oleh ahli keluarga mereka. Pesakit mengalami kancing gigi kebiasaannya kerana mereka mengalami ketakutan. Tiada simptom berjalan dalam tidur yang dialami para pesakit kerana mereka tidak sampai ke tahap demikian. Mimpi-mimpi tersebut adakalanya berlaku secara serentak dan adakalanya dialami satu daripadanya oleh pesakit. Umumnya, pengalaman pesakit adalah menyamai, menghurai, dan menambah teori kajian. 
Para perawat menerima simptom tersebut sebagai pedoman umum. Namun, mereka bersikap berhatihati terhadap kesahihan simptom tersebut dengan merujuk kepada kesan selepas rawatan. Jika mimpi berkurangan atau hilang selepas rawatan, ini bermaksud simptom mimpi tersebut adalah akibat histeria rasukan jin. Pengesahan sebegini adalah kerana bacaan ruqyah adalah bacaan pendinding mukmin daripada segala gangguan makhluk halus. Bacaan sebegini memberi kesan terhadap jin berdasarkan banyak dalil daripada al-Quran, Sunah, teori dan pengalaman perawat serta dapatan pengkaji kontemporari.

Hadis-hadis Nabi SAW pada jadual 2.1 menunjukkan satu prinsip umum bahawa segala mimpi yang buruk adalah daripada gangguan syaitan dan jin. Berkenaan hadis pertama pada jadual 2.1, iaitu riwayat al-Bukhārì (2001: 3292), al-'Ayní (t.th.: 180) menunjukkan bahawa al-Hulm ialah mimpi yang buruk, iaitu penipuan, kejahatan, dan apa-apa yang dinisbahkan kepada syaitan bagi menimbulkan buruk sangka, kesedihan, dan kurang rasa syukur. Berdasarkan huraian hadis ini, al-'Ayni tidak menentang segala pengalaman pesakit dan perawat untuk disandarkan kepada simptom histeria rasukan jin. Hal ini demikian kerana beliau menyatakan bahawa mimpi buruk adalah sebagai 'penipuan, kejahatan dan apaapa yang dinisbahkan kepada syaitan'.

Bahkan, zahir lafaz hadis kedua pada jadual 2.1 menunjukkan bahawa simptom mimpi buruk yang dialami sahabat Nabi SAW secara peristiwa khusus, iaitu 'seseorang bermimpi melihat kepalanya terputus' (Muslim, t.th.: 2268 dan Ibn Mājah, t.th.: 3913, disahihkan Albāni, 2002). Nabi SAW terus menyatakan simptom mimpi tersebut adalah daripada permainan syaitan dan menasihatkan sahabat tersebut agar tidak menceritakannya kepada orang ramai. Al-Nawawi (1971: 25) mensyarahkan hadis tersebut bahawa mimpi yang buruk juga diciptakan oleh Allah SWT. Namun, segala mimpi buruk disandarkan kepada syaitan kerana gangguan, bisikan dan godaannya.

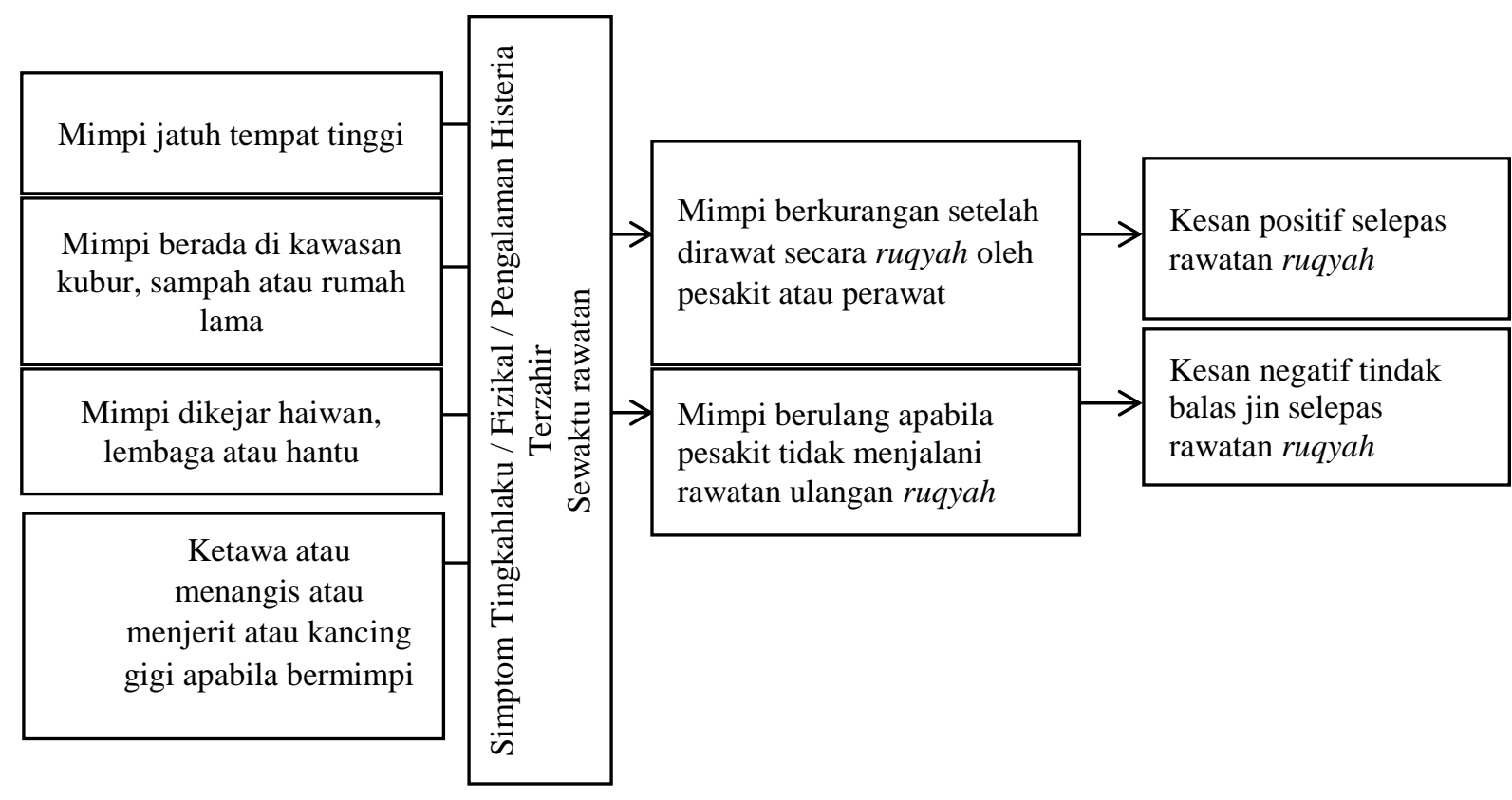

Carta 5.1: Ciri Khusus Simptom Mimpi Pesakit Histeria Rasukan Jin 
Mafhūm mukhālafah atau lafaz tersirat daripada zahir hadis ketiga pada jadual 2.1 menunjukkan bahawa kemampuan syaitan adalah menyerupai sesuatu selain Nabi SAW dalam mimpi (Ibn Mājah, t.th.: 3900, disahihkan oleh Albāni (2002: 2729). Al-'Ayni (t.th.: 154) menyatakan apabila seseorang mendakwa bermimpi bertemu Nabi SAW, hendaklah dipastikan keadaan rupa paras insan dalam mimpi tersebut sebagaimana rupa Nabi SAW yang diceritakan dalam sirah baginda. Jika menyalahi apa yang disebut dalam sirah, maka seseorang itu tidak bermimpi berjumpa Nabi SAW. Bahkan, dia bermimpi bertemu dengan syaitan. Hal ini demikian kerana syaitan mampu menyamar menjadi orang soleh dalam mimpi untuk menipu seseorang (Ibn Taymiyyah, 1985). Berdasarkan hadis dan huraiannya yang telah dibentangkan adalah jelas bahawa hadis-hadis Nabi SAW secara tidak lngsung membenarkan teori pengalaman perawat berkenaan simptom mimpi histeria rasukan jin. Hal ini berdasarkan lafaz umum hadis dan huraiannya yang bermaksud 'apa-apa jenis mimpi menakutkan' adalah daripada syaitan.

\subsection{KESIMPULAN}

Kesimpulannya, segala simptom mimpi histeria rasukan jin dari sudut pengalaman pesakit, keluarga pesakit dan perawat adalah menepati maksud hadis Nabi SAW dari sudut mimpi yang mengancam emosi pesakit dengan memberi ketakutan sebagai senjata untuk melemahkan psikologi pesakit. Hal ini demikian kerana hadis Nabi SAW dalam bab ini berbentuk umum mewakili semua mimpi yang menakutkan. Berdasarkan maksud umum hadis, mimpi histeria gangguan emosi juga sebahagian daripada gangguan syaitan kerana mengandungi unsur kejahatan dan ketakutan. Justeru, pengalaman perawat berkenaan simptom fizikal rasukan jin sewaktu dirawat dan kesan selepas rawatan ruqyah terhadap fizikal dan mimpi pesakit membezakan simptom mimpi histeria rasukan jin berbanding mimpi akibat gangguan emosi dan mimpi gangguan syaitan. Terdapat perbezaan antara istilah 'rasukan jin' dengan 'gangguan jin'. 'Rasukan jin' bermaksud 'kemasukan jin' dan sebahagian daripada bentuk 'gangguan jin'. Manakala, 'gangguan jin' tidak semestinya bermaksud 'rasukan jin' dan boleh membawa maksud 'godaan jin' untuk menakutkan atau melakukan maksiat sahaja. Mimpi buruk pesakit kebiasaannya akan beransur kurang dan menghilang setelah dirawat secara ruqyah. Hal ini demikian kerana ruqyah yang menjadi subjek dalam kajian ini adalah daripada jenis ruqyah yang bertujuan menghindarkan rasukan dan gangguan jin. Sukar dibezakan antara pesakit rasukan biasa atau al-mass, sihir atau saka kerana simptom mimpi yang dinyatakan oleh perawat kesemuanya mempunyai persamaan antara satu sama lain, iaitu sebagai simptom mimpi rasukan jin secara umum.

\section{RUJUKAN}

'Abd Allah bin 'Abd al-Hamid Al-Athari,. (t.th). Al-Shaytan 'Aduwwuka al-Awwal. (t.tp): Dar al-Ibn Khuzaimah.

Abi 'Ubaydah, Mahir bin Salih Ali al-Mubarak. (1995). Fath al-Mughith Fi al-Sihr wa al- 'Ayn wa Mass alIblis. Riyad: Dar al-'Ulum al-Sunnah li al-Nashar.

Al-'Ayni, Abu Muhammad Mahmud bin Ahmad bin Musa bin Ahmad bin Husin al-Ghaytabi al-Hanafi Badr al-Din. (t.th.). 'Umdat al-Qari Sharh Sahih al-Bukhari. Beirut: Dar al-Ihya' al-Turath al'Arabi.

Albani. Muhammad Nasir al-Din. (2002). Silsilah Ahadis Al-Sahihah Wa Shaiun Min Fiqhiha Wa Fawaidiha. Riyad: Maktabah li al-Nashar Wa al-Tawzi‘.

Al-Ma'ani, Abu al-Barra' Usamah bin Yasin Ali. (2000c). Al-Qawl Mubin Fima Yatrudu Bayna al-Jin wa al-Shayatin. Jordan: Dar al-Ma'aliyy.

Al-Ma'ani, Abu al-Barra' Usamah bin Yasin. (2000a). Fath al-Haq al-Mubin Fi Ahkam Ruqa al-Sar' wa al-Sihr wa al- 'Ayn. Jordan: Dar al-Ma'ali. 
Ezwan Rafiq Husin et al. / UMRAN - International Journal of Islamic and Civilizational Studies. Vol.2 No.2 (2015) 30-44

Al-Ma'ani, Abu al-Barra' Usamah bin Yasin. (2000b). Manhaj al-Shara' fi Bayan al-Massi wa al-Sar'. Jordan: Dar al-Ma'aliyy.

Al-Nawawi. Muhy al-Din Abi Zakariyya Yahya bin Sharaf al-Nawawi al-Dimashqi. (1971). Al-Minhaj Sharh Sahih Muslim bin al-Hajjaj. Beirut: Dar al-Ihya' al-turath al-Arabi.

Al-Shafi‘e, Muhammad bin Idris. (1940). Al-Risalah. Mesir: Maktabah al-Halabi.

Al-Shahodh, 'Ali bin Nayf. (2011). Al-Muhadhab Fi 'Ilaj al-'Ayn wa al-Massi wa al-Sihr. t.p.: Pahang Darul Makmur.

Al-Shatibi, Ibrahim bin Musa al-Lakhami al-Gharnati al-Maliki. (2002). Al-Muwafaqat Fi Usul al-Fiqh. 'Abd Allah Darraz. (Eds.). Beirut: Dar al-Ma'rifah.

Badar 'Abd al-Hamid Hamisah. (2010). Tahdhir Ahl al-Iman Min Itba'Khutuwat al-Shaytan. t.tp: t.p.

Bukhari, Muhammad bin Isma'il Abu 'Abd Allah al-Bukhari al-Ja'fi. Sahih al-Bukhari. t.tp: Dar al-Tawq al-Nashar.

Dayan, J, dan Olliac, B. (2010). From Hysteria And Shell Shock To Posttraumatic Stress Disorder: Comments On Psychoanalytic And Neuropsychological Approaches. Journal of Physiology, Paris: $104,296-302$.

Ezwan Rafiq Husin, Husin Junoh, Tamar Jaya Nizar dan Kamarolzaman Md. Jidi. 2015. Kajian Kes Simptom Fizikal Histeria Rasukan Jin Di Malaysia. Jurnal UMRAN. International Journal of Islamic and Civilizational Studies. Fakulti Tamadun Islam, UTM, Skudai: (2) 1-20.

Haron Din, Mokhtar Kassan dan Azizan Ramly. (2015). Kaedah Merawat Saka. Selangor: Pts Millenia Sdn. Bhd.

Haron Din. (2011). Rawatan Penyakit Akibat Sihir. Kaedah Mengelak, Menentang dan Mengatasi Sihir. Bandar Baru Bangi: Persatuan Kebajikan dan Pengubatan Islam Malaysia.

Henry Ey. 1982. Hysteria. (Roy, Alec. Eds.). Chichester: John Wiley \& Sons.

Ibn Battal, Abu al-Hasan 'Ali bin Khalaf bin 'Abd al-Malik. (2003). Sharh Sahih al-Bukhari li Ibn Battal. Riyad: Maktabah al-Rashad.

Ibn Majah, Abu 'Abd Allah Muhammad bin Yazid al-Qazwini. (t.th.). Sunan Ibn Majah. t.tp: Dar Ihya' alKutub al-'Arabiyyah.

Ibn Taimiyyah, Ahmad Taqi al-Din. (1989). Al-Dalil wa al-Burhan 'ala Sar' al-Jin li al-Insan. t.tp.: Maktabah al-Sundus.

Ibn Taymiyyah, Taqi al-Din Abu al-'Abbas Ahmad bin 'Abd al-Halim bin 'Abd al-Salam bin 'Abd Allah bin Abi al-Qasim bin Muhammad Ibn Taymiyyah al-Harrani al-Hanbali al-Dimashqi. (1985). AlFurqan Bayna Awliya' al-Rahman wa Awliya' al-Shaytan. Damshiq: Maktabah Dar al-Bayan.

Khadher Ahmad. (2012). Analisis Hadis-Hadis Mengenai Rawatan Sihir Dalam al-Kutub al-Sittah: Aplikasi di Pusat Rawatan Islam di Malaysia. Tesis Ijazah Doktor Falsafah, Universiti Malaya.

Matus, J. L. (2008). Historicizing Trauma: The Geneacology of Psychic Shock In Daniel Deronda. Victorian Literature and Culture. 36: 59-78. 
Ezwan Rafiq Husin et al. / UMRAN - International Journal of Islamic and Civilizational Studies. Vol.2 No.2 (2015) 30-44

Mohamed Hatta Shaharom. (2008). Etika Perubatan Islam Dan Isu-Isu Psikiatri. Kuala Lumpur: Dewan Bahasa Dan Pustaka.

Muhammad bin Sa‘id al-Saqran. (t.th). Rahah wa Itmi’nan. (t.tp). Dar al-Qasim.

Muslim, Muslim bin al-Hajjaj Abu al-Hasan al-Qushairi al-Naysaburi. (t.th.) Sahih Muslim. Beirut: Dar Ihya' al-Turath al-'Arabi.

Ranjit Kumar. (2005). Research Methodology A Step By Step Guide For Beginners. 2nd (Ed.). London. Sage Publications.

Ray, S. L. (2008). Evolution of Post Traumatic Stress Disorder and Future Directions. Archieves of Psychiatric Nursing. 22(4): 217-225

Sharifah Norshah Bani Syed Bidin. (t.th.). Ayat-Ayat al-Quran Sebagai Terapi Kerasukan Jin: Analisis Dari Ayat-Ayat Ruqyah Shar'iyyah. Centre of Quranic Research International Journal. Hlm: 107-138.

Swanborn, P. G. (2010). Case Study Research. Los Angeles: Sage Publications Inc.

Usamah al-'Awdi. (2009). Ahkam Tafsir al-Ru'ya wa al-Ahlam Fi al-Quran al-Karim wa Sunnat alMutahharah. Kaherah: Turath al-Salafiyyah Li Nashar al-'Ilm.

Wahid, 'Abd al-Salam Bali. (1997). Wiqayah al-Insan min al-Jin wa al-Shaytan. Kaherah: Maktabah alTabiin. 